\title{
Negotiating face in feedback conferences: a linguistic ethnographic analysis
}

\section{Introduction}

Post-observation feedback conferences are a common feature of teacher education programmes. Most feedback is dyadic, between a 'trainer' and a 'trainee'. However, in many training courses designed to support teachers of English as a foreign/second language, feedback is often held in groups, with one trainer and a group of trainees. In this case, the feedback conference is a semi-public 'platform' event (Goffman, 1981) and, as such, carries a particular set of expectations in terms of speaking rights and discourse functions.

This article will uncover a number of these expectations. It will show that group feedback has its own norms of interaction which include the right to perform face threatening acts, or, to use Tracy's (2008) term, acts of 'reasonable hostility'. Nevertheless, participants also perform acts which challenge the norms and therefore can be considered more conventionally face threatening. The article will make the case for using both linguistic and ethnographic data to uncover face work, and will argue that it is through conjoining linguistic and ethnographic approaches that detailed, contextualised analyses emerge.

Before examining the data which gives rise to these claims, I will first explore in a little more detail some of the theoretical issues introduced here, namely current approaches to the study of face, and the methodological warrant for the research method, that is, linguistic ethnography. I will then briefly describe the setting and the data collection methods in order to contextualise the study.

\section{Current directions in research on face and politeness}

Face is a firmly established theoretical construct and central to many aspects of pragmatics research. The seminal work of Goffman (1967) influenced Brown and Levinson's important work on politeness (1987), in which politeness is to a great extent conflated with face. Since then, research in this area has continued, for the most part, to examine face and politeness together, and often the focus has been on politeness in particular. For example, researchers have developed localised understandings of politeness in different cultural settings, and argued that a number of the claims made by Brown and Levinson cannot be applied beyond particular western contexts (Gu,1990; Blum Kulka,1992; Ide,1993; Eelen, 2001). Others have looked to develop theoretical constructs such as lay and linguistic understandings of (im)politeness (Watts, 2003) and developed definitions of impoliteness and rudeness (Bousfield and Locher, 2008; Bousfield, 2010; Culpeper, 2005, 2008; Terkourafi, 2008). Indeed, the writing on politeness research has been so in-depth and voluminous that Haugh (2007) was recently able to critique the critiques, questioning the epistemological and ontological assumptions underpinning post-modern discursive approaches to politeness and calling for research into politeness to focus on how politeness is achieved through the 'sequential unfolding of interaction' (ibid:295), that is, to focus on not utterance but on discourse (see too Arundale, 2010).

This shift of attention onto discursive aspects of politeness is also reflected in studies of face, which have been marked by a move away from individual perspectives towards a more interactional focus. Some researchers have considered socially-situated models of face (Spencer-Oatey, 2002, 2007) or critiqued Goffmanian notions of face upon which much of Brown and Levinson's work is premised (Bargiela-Chiappini, 2003; Arundale, 2006). Arundale's recent research (2010) conceptualises face as 'a social phenomenon arising in the conjoint co-constituting of human relationships' (Arundale, 2010: 8) and argues for an analysis 
of talk from the participant's rather than the analyst's perspective, Haugh and BaregielaChiappini (2010), in their introduction to a Journal of Pragmatics special issue on Face and Interaction, concur with Arundale, and go on to argue that in order to develop a coherent theory of face 'on its own terms' (2010:2073), it should not (always) be conflated with politeness. They then contend that face should be analysed at the level of interaction rather than as considering face as residing with the individual (a criticism they level at Goffman's conceptualisation) Consistent with this view is their preference for 'examining samples of reallife interaction' (2010:2074), a view, they state, not always shared by others working in pragmatics (ibid).

The focus on analysing face interaction raises a further issue. Interactions are situated. Cultural norms of interaction, personal relationships, and the speech genre (Günthner and Knoblauch, 1995) in which participants are involved all exert influence both on what is said and how this talk is interpreted by participants. While Geyer (2010) and Eelen (2001) both argue against over-reliance on contextual features to explain behaviour and interpretations of it, it is equally important that contextual features are not ignored when analysing face in talk. Indeed, it is through contextual detail that Geyer (2010) is able to identify some of the 'tacit norms' of interaction in the Japanese staff rooms she describes and so analyse the threat to participants' face of institutional teases.

Gathering contextual and situated detail, however, is difficult, requiring researchers to spend time in the field observing interactions, developing an understanding of the 'site' (and/or community of practice, in Geyer's (2010) case), and taking opportunities to talk to participants. It is hardly surprising then, that apart from a few notable exceptions (in particular, Mullany, 2008; Tracy, 2008; Geyer, 2010) most studies of face (and, indeed, politeness) do not explore or invoke these situated and contextual factors to any great extent. Instead, researchers take data from television programmes (for example, Bousfield 2008; 2010; Culpeper, 2005, 2008; Garcia-Pastor, 2008; Limberg, 2008), courtroom transcripts (for example, Cotterill, 2010) or use recorded interactions from research participants (for example, Holmes and Marra, 2004; Holmes and Schnurr, 2005) in order to explore face (and politeness) and to develop theory. While such extracts can be illuminating, particularly in terms of the development of theory, the researchers are rarely present at the interactions and so cannot draw on contextual and situated details in their analyses.

In contrast to such studies, this article presents an analysis of face that draws on talk-ininteraction (from transcribed recordings), the participants' perspectives and contextual and situated detail (from fieldnotes, focus groups and interviews) in order to provide an analysis of face and face threatening acts in teacher training feedback conferences. In doing so it responds to Haugh's (2007:311) call for studies to be ethnographically informed:

One way in which to tease out aspects of the context beyond those available from the micro-analysis of talk-in-interaction data, might be to draw from more ethnographically-informed interactional analyses and thereby establish the viability of the analysts' interpretations in relation to a particular theoretical framework.

Linguistic ethnography provides both the methodological tools for collecting and analysing data and the theoretical framework in which to establish interpretations that Haugh calls for. It is to this I now turn.

\section{Linguistic Ethnography}

Linguistic ethnography (LE) is a growing body of research which 'marries' (Wetherall, 2007) linguistics and ethnography to produce detailed and nuanced studies of talk in particular 
contexts in order to 'understand the social processes we are involved in' (Rampton, 2007:12). Linguistic ethnographers hold to a set of ontological precepts, such as rejecting 'the objectivism found in e.g. structuralist linguistics' (Rampton et. al, 2004:5; Rampton, 2007), and 'the overriding importance of reflexivity 'about their own intellectual assumptions (Rampton et. al, 2004: 5). Epistemologically, those working within linguistic ethnography believe that:

language and the social world are mutually shaping and that close analysis of situated language use can provide both fundamental and distinctive insights into the mechanisms and dynamics of social and cultural production in everyday activity (ibid:2).

For many, LE offers a new approach to researching language and ethnography. Situating themselves within 'the new intellectual climate of later modernity and poststructuralism' (Creese, 2008:229; Rampton et. al, 2004) researchers foreground a reflexive approach to data collection and analysis in which the researcher, is rigorously accounted for and where 'truth claims made by the research' are informed by the role the researcher has played in this research (Tusting and Maybin, 2007:579).

A number of different analytic tools for data collection and analysis, such as participant observation (data collection) and Conversation Analysis (data analysis) are employed by those working under linguistic ethnography. These derive from both ethnographic and linguistic traditions. Rampton et. al (2004) characterises the relationship between linguistics and ethnography as 'tying ethnography down' and 'opening linguistics up' (2004: 4) so that the value of discourse analysis in ethnography is foregrounded (Creese, 2007).

The range of data sets in this study - fieldnotes, audio recordings and interviews facilitate a focus on contextual, linguistic and paralinguistic features of the feedback event which are telling in terms of how participants respond to on-going interaction. What is more, as my data set also includes post-feedback interviews, the analysis also benefits from 'evaluative reactions' from both trainers and trainees, a data set not often found in studies of face and politeness (Spencer-Oatey, 2007) but which, nonetheless, can shed further light on participants' intentions and understandings.

\section{Setting, participants and data}

The research was carried out at an adult education college in the UK on two certificate courses in English language teaching to adults (CELTA). Teaching practice was an integral part of the programmes, with each trainee doing 6 hours of teaching altogether, which he/she had to pass.

The feedback conference took place approximately 30 minutes after the end of teaching. As previously mentioned, it was a group event with a trainer and up to four trainees taking part. It lasted for between forty-five minutes and an hour. Four trainers and nine trainees took part in the research project. There were three female and one male trainer, all between the ages of 35 and 45 . They had between three and seven years experience of training on CELTA courses. The trainees were between the ages of 22 and 35 , and four were female and five male. Although it was a pre-service course, three of the participants had had some teaching experience, but only one had taught English, and then only for nine months.

Data were collected on a ten week semi-intensive course and a four week intensive course. The feedback sessions were all audio recorded and some were video recorded. As an observer 'participating-in-order-to-write' (Emerson et al.,1995:19), I controlled the equipment and also took notes during the feedback, which I later wrote up into field notes. I also interviewed the trainees in their groups and the trainers before the start and at the 
end of their courses. In the post-course interviews, I asked participants to comment specifically on recorded data and on transcriptions of these. Although I had worked at the centre in which the research took place for many years as a trainer and knew the institution well, I was no longer a member of staff when I conducted the research and I was not involved in any aspect of the course in any capacity. Feedback was the sole focus of the study, and I did not observe teaching practice or the lesson preparation. The British Association for Applied Linguistics' (2006) ethical guidelines for applied linguistics research were followed, including informed participant consent, with participants being assured of anonymity and confidentiality.

\section{The Rules of the Game in Feedback Conferences}

Thompson (1991: 27), cited in Roberts and Sarangi (2001:175), uses the metaphor of having a feel for the game to explain Bourdieu's concept of habitus, that is, 'a set of dispositions that incline us to behave - to act and react - in a certain way' (Roberts and Sarangi 2001:175). Roberts and Sarangi extend this metaphor to show how adult learners in a classroom can be disadvantaged by not playing by 'the rules of the game' (ibid) when they do not reproduce the behaviours sanctioned by their particular teachers. Likewise, in feedback, there are rules to follow in order to be positively evaluated by trainers and so pass the course and receive certification.

The rules of feedback were established through a genre analysis (author, 2008). Genre is a construct used by a number of researchers working within different traditions. For the current study, the work of Bakhtin on speech genres was particularly useful (1981; 1986) as was recent work in linguistic anthropology (for example, Briggs and Bauman, 1992). Rampton (2006: 128) summarises genre from this perspective as:

a set of conventionalised expectations that members of a social group or network use to shape and construe the communicative activity that they are engaged in. These expectations include a sense of the likely tasks on hand, the roles and relationships typically involved, the ways the activity can be organised, and the kinds of resources suited to carrying it out.

Each feedback conference was analysed according to these categories of expectation the tasks on hand, the roles and relationships, the organisation of activities and the resources suited to carrying them out. It was found that feedback comprised five central tasks and that while these were a part of each conference, they did not always occur in the same order and often overlapped (see, too, Waite, 1995). Each task required trainers and trainees to orient to different activities, performing different roles and different discourses. The tasks are listed in table 1, as are the activities, roles and discourses, conflated as the rules of the game:

Table 1: Generic expections of the feedback conference

\begin{tabular}{|l|l|}
\hline Tasks & Rules of the Game \\
\hline 1. Self-evaluation & $\begin{array}{l}\text { Trainee discusses his/her own lesson and highlights } \\
\text { strong and weak aspects. Turns are generally short. }\end{array}$ \\
\hline 2. Trainer Feedback & $\begin{array}{l}\text { Trainer critiques trainee's lesson with positive and } \\
\text { negative evaluation, and provides advice and suggestions. } \\
\text { Trainees take on board feedback 'gracefully', } \\
\text { demonstrating they are receptive learners. }\end{array}$ \\
\hline 3. Peer-feedback & Trainees provide feedback to their peers on the strengths \\
\hline
\end{tabular}




\begin{tabular}{|l|l|}
\hline & $\begin{array}{l}\text { and weaknesses of the peer's lessons. Turns, if long, tend } \\
\text { to provide a lot of descriptive comment. }\end{array}$ \\
\hline 4. Questioning & $\begin{array}{l}\text { Trainers ask trainees a series of questions about particular } \\
\text { sections of their lessons. }\end{array}$ \\
\hline 5. Clarification & $\begin{array}{l}\text { Trainers and trainees talk about things not directly } \\
\text { relevant to the lesson taught, for example, assignments. } \\
\text { This is the only phase that is usually trainee-initiated. }\end{array}$ \\
\hline
\end{tabular}

\section{Table 1: Feedback Tasks and Rules of the Game}

As can be seen in table 1, the rules of the game in feedback include performing speech acts such as criticism, negative evaluation and questioning, which might be face threatening (Brown and Levinson, 1987) in more usual contexts. Tracy (2008), however, argues that in some situations (in her case, the open meetings of school boards in the USA) certain types of face-attack are legitimate as they are 'normative ideals' of the discourse context (p.170), that is, they comply with the rules of the game. She calls these face threats 'acts of reasonable hostility'. She further argues that acts of reasonable hostility:

are adorned with at least a piece or two of positive jewelry. These conventional 'politeness' moves convey to observers that a speaker's criticism is not centrally motivated by inflicting hurt on the other. To be judged 'reasonable' hostile expressions needs to include discourse tokens that imply to most observers that personal hurt was a by product of needed criticism rather than its central goal. (Tracy, 2008: 187)

It will be argued here that certain face threatening acts in feedback conferences are similarly 'reasonable' as they are required by the genre (which is fundamentally about delivering and receiving positive and negative evaluation) and are 'adorned with 'positive jewelry' (that is, mitigation and hedging) in order to demonstrate that personal hurt is not the main purpose of the face threat. However, it will also be shown that other face threatening acts seem to go beyond the norms of behaviour and disrupt the expectations of the feedback genre. These face threatening acts may also inflict personal hurt or, at least, be designed to do so. At these points in the discourse, participants work hard to negotiate the threat to face, either to downplay its importance or to enhance its strength, with different participants working towards different ends. It is at these junctures that the intertextual gap (Briggs and Bauman, 1992) between the expectations of the feedback genre and its realisation in practice is exposed, uncovering the 'political struggle' Rampton (2006:31) between participants as they go about the business of resisting, contesting or complying with the underlying purposes of feeding back.

In the following sections, three tasks from the generic expections of feedback will be explored with regard to face: trainer feedback, peer feedback, and questioning. As both selfevaluation and clarification generally presented fewer issues with regard to face, these will not be discussed here (but see author, 2010, for an analysis of self-evaluation).

\section{Trainer feedback}

Discourses of negative evaluation, which in many contexts would be perceived as facethreatening (Brown and Levinson 1987), were common and accepted by trainers and trainees, particularly when performed by trainers. Trainers regarded providing evaluation as part of their role, as this trainer explained in the pre-course interview:

\section{Extract 1}


My function is to ...encourage them to make comments on each other and to reflect on their own lessons erm (.) and also to give my own appraisal of what they've done.

Trainees also accepted negative evaluation as a necessary evil, as is shown in this postcourse interview:

\section{Extract 2}

I think the most uncomfortable thing is when you're criticised by the tutor but it's also the most useful thing, I've got to say. I mean you might not like it while it's actually happening but when you go back and kind of reflect on it you learn.

Indeed, quite often the trainees accepted the negative evaluation in a seemingly disinterested (neutral) 'graceful' way, that is, not contesting the negative evaluation:

\section{Extract 3}

Trainer 1: $\quad$ So as to the usefulness of that activity, probably not the most useful.

Trainee J: Okay

However, accepting negative evaluation 'gracefully' was not always achieved by trainees. In the following extract, the trainer criticises the trainee's teaching of verb patterns, in particular the rules that pertain to verb patterns and present participles. There is little mitigation here in the trainer's talk: the negative evaluation is clear.

\section{Extract 4}

1. Trainer 2: actually at no point (.) I know you put them in two boxes $=$

2. Trainee $\mathrm{C}:=$ I did explain the 'ing'

3. Trainer 2: but at no point did you explicitly say look or raise their awareness about

4. the fact that some of them go with 'ing' and some of them the =

5. Trainee C: $=$ I didn't yep

6. Trainer 2: = infinitive and that you know that is an issue

7. Trainee C: It's a fair cop

8. Trainer 2: yep

9. Trainee C: ((laughs))

10. Trainer 2: yep yep (.) yep

11. Trainee C: ((laughs))

12. Trainer 2: yep yep

In line 1, the trainer prepares to deliver a potentially face threatening act of criticising performance, when he states, 'actually at no point'. However, he then pauses and instead of making the criticism, he acknowledges that the trainee did do something well in this part of the lesson ('I know you put them in two boxes'). This can be seen as mitigating: it 
is not that the criticism will not be delivered but that some positive politeness work is necessary in order that the trainee understands it is an act of reasonable hostility (Tracey, 2008).

At this point, the trainee interrupts, and she contests the trainer's interpretation of her lesson as not having drawn learners' attention to the present participle -'I did explain the "ing" (line 2). The trainer disagrees, the 'but' at the beginning of line 3 signalling opposition, and he then goes on to highlight the features of 'ing' that she should have covered. There is no mitigation here (lines 3 and 4) - the trainer delivers the criticism in a bald on-record way (Brown and Levinson, 1987). The trainee has a choice at this point: either she can continue to dispute the trainer's evaluation (and so risk annoying the trainer and threatening his face) or she can show compliance and take on board the trainer's critique, a more pragmatic approach in the circumstances. She choses the latter course ('I didn't yep'), interrupting the trainer's flow of negative evaluation. However, perhaps because of the admission, the trainer's next comment (line 6) is less direct, including the softner 'you know'.

The final direct comment comes from the trainee at line 7. She states that 'It's a fair cop'. The trainer agrees (yep) but instead of this closing down the talk, the trainee laughs (line 9) which seems to act as the first part in an adjacency pair as it elicits a series of 'yeps' from the trainer. The trainee's second laugh (line 11) has a similar effect.

There is clearly negotiation of face needs in this section of feedback. The trainer at the beginning of the extract moves to protect the trainee's face by offering some positive evaluation instead of delivering a clear criticism (line 1). However, the trainee responds to the criticism rather than the praise and instead of accepting it gracefully, as the per the rules of the game, contradicts the trainer's account of the lesson (line 2). This is face threatening to the trainer, who does not accept the trainee's version. Instead, he delivers the criticism again, this time delivering it in full and so upgrading its strength. The lack of adornment suggests that the trainer is no longer as concerned with the trainee's face needs. The trainee, perhaps recognising she is in danger of not behaving like a compliant trainee, then interrupts the trainer, this time to accept the criticism ('it's a fair cop').

The metaphor, often used ironically in day-to-day talk, is telling in terms of the trainee's attitude to the criticism: she does not say 'I agree' but 'you caught me out', a different speech act altogether. First of all, it allows the trainee to acquiesce with the trainer's evaluation (the assessment is 'fair') and so demonstrate compliance and an acceptance that she did not teach the grammatical rule effectively. However, it also shows that the trainee views feedback as an aymmetrical 'them and us' event in which part of the trainee's task is not to get caught doing something wrong, in this case, teaching grammar badly. In this, she has failed. Finally, it implicitly recognises that the original defence - 'I did explain the '...ing' - was not relevant to the action under scrutiny (that of separating verbs according to syntactic behaviour). In other words, it allows the trainee to retract her earlier face threatening remark to some extent.

The metaphor also allows the trainee to accept the criticism in a humorous way and so cleverly reduces its strength (Holmes and Stubbe, 2003). Indeed, in 'making light of a serious situation' (Hay, 2000:716, cited in Locher, 2004:169) through irony (after all, feedback is not a criminal investigation but an educational forum), the trainee is able to signal both compliance and resistance.

The comment seemed to hit the mark: the trainer is only able to respond with 'yep', which he utters six times, showing perhaps that an addressee 'can react less easily to an ironic utterance than to direct criticisms or insults' (Locher, ibid).

Laughter is also relevant in this extract. At line 9, trainee $\mathrm{C}$ laughs when the trainer agrees he has caught her out (line 8) and laughs again at line 12 after the trainer 
reiterates the fact ('yep yep'). Laughter can serve a number of different functions from alignment (Soilevuo Grønnerød, 2004) to embarrassment and confusion (Locher, 2004) to managing tension (Partington, 2006). In this extract, the laughter is only performed by the trainee, that is, the trainer and other trainees do not join in (Sacks (1992:571) suggests that laughter is not done 'right' if there is no joining in). What is more, the laughter comes directly after the trainee has been positioned into receiving a criticism, and admitting that she had been caught out. Given these discoursal realities, it is reasonable to suggest that trainee C's laughter has at least two functions. Following, as it does, the 'laughable' (Thonus 2006:334), it seeks to reduce the tension that the performance of this face threatening act might create. As it goes on and others do not join in, it may also signal trainee C's embarrassment: she has not been able to persuade the trainer of her competence in teaching grammar and she has also been caught out in trying to defend an indefensible position.

The linguistic analysis of this extract shows that face is negotiated between participants utterance by utterance. The trainer, for the most part, seems to abide by the rules of the game, mitigating negative evaluation and softening criticism. However, in offering a bald on record criticism in line 3 , he potentially worries the generic boundaries and threatens the trainee's face. In doing so, the trainer provides the trainee with a choice: agree with him or risk negative evaluation. The trainee, on the other hand, seems at first, in danger of breaking the rules of the game, by disagreeing with the trainer's opinion. However, once the unmitigated criticism has been given, she swiftly changes her stance and agrees that she did not teach the grammar point effectively. This seeming capitulation then gives way to a more ambiguous utterance - it's a fair cop - which seems both to align herself with the trainer's viewpoint at the same time as contesting it.

Nevertheless, this linguistic analysis, while helpful, does not in itself provide evidence for why the trainee in particular negotiates a fairly precarious path. While it could be that the trainee was unhappy with the nature of the criticism (perhaps she believed she had taught the grammar lesson successfully), my fieldnotes suggest that there was another reason for the behaviour: resistance to criticism. The following note is one of four in which I draw attention to the trainee's defensive positioning:

\section{Extract 5}

This trainee is still quite defensive (when the trainer criticised her instruction giving, the trainee was keen to say how giving instructions had always been a strength).

It seems that although the trainee understood the rules of the game and, it could be argued from other data, the value of feedback, when criticism was levelled directly at her, she found it difficult to take it on board gracefully, as the rules of the game require.

Culpeper (2005) notes this tension in recipients of legitimate face attack. He suggests that even in contexts where face attack is 'normalised', such as in the army or on game shows such as 'The Weakest Link', participants are often not able to 'decontextualise' the face attack and take it on board. He argues that this is because the face threatening act emerges as more salient than the context in which the participant finds $\mathrm{him} /$ herself. In this case, faced with criticism, the trainee reacts as she might have done in a more usual context, defending herself and disagreeing with the critique. Interestingly, in her post-course interview, this trainee suggested that she had found the criticisms made by trainers to be too 'sugar-coated'. Her reactions in feedback, however, suggest otherwise.

\section{Peer- feedback}


Peer-feedback is a unique feature of group feedback. It comprises trainees delivering positive and negative comments to each other about each other's teaching. As part of the training programme, trainees were expected to observe their peers carefully as they taught, perhaps taking notes or completing an observation schedule, and then, in feedback, they took turns to focus on the strengths and weaknesses in the lessons they had seen. Feeding back to peers was not a task that all trainees seem to value or were happy to perform, as this trainer explained in the pre-course interview:

\section{Extract 6}

But also I think it's actually quite difficult that bit, because I think a lot of trainees do tend to think it's only about them, and therefore the whole issue of observing peers is quite an interesting one in that you have to actually persuade people to do that and try to convince people that looking at other people's teaching is actually extremely useful.

'Peer-feedback' on the programmes reported on here tended to consist of a good deal of description (of what happened in the lesson) and of positive feedback. Where feedback was negative, it was unelaborated, hedged and often linked by the trainee delivering the feedback to a weakness in his/her own performance, as if somehow to share responsibility for the weakness. Most of these features are present in the following trainee's peer feedback: unelaborated negative feedback (italics), praise (underlined), link to weakness in own performance (bold):

\section{Extract 7}

I thought that was quite good. I wouldn't have thought of that and really enjoyed the game at the end, didn't they, making the sentences. I thought () they seemed to really enjoy that activity of putting all the words together. I thought that was good cos that gave them the chance to use what they were learning, put it in the proper context. Um the only thing of working on, I thought, was the same as what I did last week, when somebody asks um says the wrong answer. I did the exactly the same and I said 'Ooh no!'. Um and then, like in my feedback, I think it was you suggested didn't you say to say something like ' $O$ h why did you think that?' or, 'Did everybody else get the same answer?' so to try and draw them out why they said no. So that stood out cos it was the same as what I did ((laugh)).

Although all trainees had a warrant for providing negative feedback to each other, most, then, did not do so to any great extent, perhaps finding the task either too difficult (they were new to teaching) or too face threatening (to both their peers' faces and their own). In other words, although negative peer evaluation was sanctioned by the norms of interaction, trainees were not generally successful at it. However, when one trainee refused to deliver peer feedback of any kind, there seemed to be a different underlying motive. Here is the extract: trainee $\mathrm{S}$ has been asked by the trainer to feedback to trainee $\mathrm{C}$ :

\section{Extract 8}

1. Trainer 2: Um, (.) trainee $S$, you you've gone () a bit quiet

2. Trainee $S$ : Sorry about that (quietly) 
3. Trainer 2: Do you want to eh start off on with trainee $\mathrm{C}$

4. Trainee C:

5. Trainer 2:

on trainee $\mathrm{C}(($ laughs $))$

6. Trainee S: Umm (...) No ((falling tone $))$ no

7. Trainer 2: No? ((rising tone))

8. Trainee S: I've I've got some thoughts sorry but I I was wasn't making

9. notes terribly well today and I've got no real structure to them so

10. I'll I I have to generalise from them

11. Trainer 2: That's alright If they've got no real structure to them that's

$12 . \quad$ fine

13. Trainee $\mathrm{S}$ : Um

14. Trainee C: ((laughing)) You've got all the right notes but not necessarily in

15. the right order ((laughs))

16. Trainee J: ((laughs))

17. Trainee $\mathrm{C}$ : ((inaudible comment))

18. Trainee 1: The exercise at the end was really interesting fun and could

$19 . \quad$ have been longer and

The trainer begins the extract by suggesting that trainee $\mathrm{S}$ has not been contributing to the discussion ('you've gone a bit quiet'), an act of reasonable hostility given that the trainer manages who speaks in feedback (note the softener 'a bit', reducing the strength of the comment) and trainees are expected to contribute (the data going up to this section show that trainee $\mathrm{S}$ has not spoken for some time). Trainee $\mathrm{S}$ apologises, but does not provide a reason for his silence. At line 3, the trainer then invites trainee $\mathrm{S}$ to start his evaluation of trainee $\mathrm{C}$. The trainer makes a mistake with the preposition, causing trainee $\mathrm{C}$ to repeat the mistake and to laugh about it (to start on rather than to start with seems to suggest that criticism will be harsher). Trainee $S$ hesitates ('Ummm') and then pauses before uttering his 'no' in falling tone. His turn initial filler and pause mark this as a dispreferred second pair part to the trainer's invitation in line 3 (Pomerantz 1984), while the falling tone on 'no' has a final quality - this is not a 'holding' no or a 'hesitant' no. That the refusal is unexpected is recoverable from the trainer's questioning 'no?' at line 7. What is more, dispreferred responses are accountable and the questioning 'no' invites trainee $\mathrm{S}$ to give an account. At line 8, trainee $\mathrm{S}$ does so through providing a reason for his inability to provide feedback ('I wasn't making notes... I've got no real structure to them') which mitigates his 'no', perhaps as he realises he has over-stepped the generic boundaries. The trainer replies encouragingly that structure is not important, accepting the trainee's attempt to re-establish himself in the talk. Trainee $C$ then makes a joke about S's note taking ('all the right notes but not necessarily in the right order', a joke almost universally recognised in the UK, having first been made in a classic 1970's comedy sketch in which the comedian defended his appalling performance on the piano with this remark). This laughable, in contrast to her remark in extract 4, draws laughter from the other trainees in the room, and covers their embarrassment, or at least confusion (Locher, 2004). Then, at line 18, trainee S starts to give detailed feedback on C's lesson.

This extract is telling in terms of playing by the rules of the game with regard to face. It is clear that trainee S's refusal to give feedback is not expected; both the trainer's 'no?' and the other trainees' laughter indicate surprise at the refusal and so some degree of face threat is apparent. However, the linguistic data alone are not enough to interrogate the no and to understand the nature of the face threatening act in terms of its being either 
an act of reasonable hostility or as transgressing the norms of acceptable behaviour. Indeed, from the linguistic data it could be argued that the trainee was unaware that his refusal was contrary. This feedback session occurred near the beginning of the course and the trainee might not at this point have understood what the rules of the game comprised. His pause before his refusal could have indicated he was thinking (the video data show he was looking down at his notes at this point) and the fact that he subsequently went on to give a detailed set of feedback comments might be interpreted as a positive reaction to the surprise of the other participants.

However, the ethnographic data, the field notes and the interview suggest a different interpretation, that of the trainee being deliberately provocative. First of all, in my field notes, I noted the refusal and its contrariness:

\section{Extract 9}

The following interaction was very odd. He said 'No' but it wasn't clear what he meant by this. ... is he challenging the trainer, the event or something else? Is he doing it deliberately or not?

From this point in the course, I also frequently noted trainee S's attitude, posture and levels of interaction when with this trainer. For example, I noted that $\mathrm{S}$ 'did not seem to get involved in the feedback', that he 'rarely if ever takes the floor independently' and that he 'just seems stubborn'. However, when the trainers swapped groups and trainee $\mathrm{S}$ had a new trainer, his behaviour changed. I noted that trainee $S$ 'really took part' in the feedback, that he 'smiled fully' and that he 'seemed readily to accept the critique'. In other words, he seemed to become more involved once a new trainer was introduced. In the post-course focus group I asked him about his relationship with the trainers. He responded:

\section{Extract 10}

Through no fault of [trainer 2's], I really, really enjoyed the things he had to say, I was delighted to change [groups] as we hadn't had any exchange of ideas for at least the last week of his fortnight and I thought, you know, a change of scenery would help.

However, it was not only the first trainer that trainee $S$ struggled to exchange ideas with. He also revealed in the focus group that he found his group difficult to work with:

\section{Extract 11}

Trainee S: I felt that () we generally exchanged like compliments and stuff after the lesson after the first few () and that repeating those was in front of the trainer wasn't really worthwhile and I didn't feel that I could make any criticisms

FC: $\quad$ Right you didn't have any to make or you didn't want to make any

Trainee S: No I had them to make

but I didn't feel I could make any

FC Right wh why didn't you feel you could make them? 
Trainee S: Just cos I didn't think they'd be received () um (..) I didn't think they'd be recei::ved () ((rising tone)) positively () maybe that's a bad expression

Not trusting his trainer to get involved in a 'genuine' exchange of ideas nor his peers to receive his criticisms 'positively' trainee $S$ demonstrates his frustration through noncompliance. This seems, on first glance, to be deliberately provocative and designed to threaten the face of the trainer (and, perhaps, the other trainees). However, while the linguistic data indicates that the trainer and trainees both interpreted the refusal as at least disruptive (the trainer challenged his refusal and the trainees made light of the situation perhaps in order to ease the tension), the ethnographic data once again allows a more nuanced interpretation. When I played extract 8 to the trainer in the post observation interview, he said:

\section{Extract 12}

it was quite strange yeah quite strange that he would say that. Is he having a really bad moment, is he asking why the hell are you asking me to give feedback 'cause she is not going to listen anyway?...I don't I didn't perceive it as a sort of (.) defiant no...I didn't perceive it as that.

For me, the participant observer, this extract is particularly telling. When the refusal happened, I was aware of its incongruity, as can be seen from my field notes in extract 9 . When I reviewed the data, I became even more convinced that the refusal had been face threatening, contesting the rules of the game, which is why I brought it to the attention of the trainer. However, my reading of the refusal was not shared by the trainer who stated:

\section{Extract 13:}

I don't think I felt threatened by that no there. I perhaps felt () a little bit you know, oh wow, why don't you know?

Of course, both emic and etic readings are possible, but these ethnographic extracts show how difficult it is to make statements about the success or not of face threatening acts, or the intention behind them given the importance of context in how they are interpreted.

What is more, it is the ethnographic data which have again allowed a detailed and nuanced analysis to emerge, an analysis which recognises the negotiated nature of face threatening acts, and which recognises the participant's interpretations can contribute to our understanding of the talk.

\section{Questioning}

Questioning in feedback consists of questions being directed to one trainee by the trainer which, if successful, leads the trainee to a 'catalytic moment' of understanding, that is, the trainee develops new knowledge as a result of the questioning (Hyland and Lo 2006:173). Questioning of intensity and frequency is only common in particular professional discourses, such as education and law. Like negative evaluation and peer feedback, it is one of the norms of interaction in feedback and trainees, for the most part, accept it. They respond positively to the questions they are asked, despite the fact that the questioning is designed to uncover 
mistakes the trainees have made or their limited knowledge and understanding of the skill of teaching English.

In the following extract, the trainer wants the trainee to understand the importance of having clear lesson aims and she pursues this agenda through a questioning discourse (underlined):

\section{Extract 13}

1. Trainer 3:

2.

3.

4. Trainee A:

5. Trainer 3:

6.

7.

8.

9. Trainee A:

10. Trainer 3:

11.

12.

13.

14.Trainee A:

15.

16. Trainer 3:

17.

18.

19. Trainee A.:

20. Trainer 3:

21.

22.Trainee A:

23.

24. Trainer 3:

25.

26.

27.

28.

29. Trainee A:

30. Trainer 3:

31.

32. Trainee:

33.

34.

35.
What sort of speaking what sort I mean you wanted them to practise speaking what sort of speaking were you working what did you hope students would get better at () at the end of your lesson?

Um (.) just yeah I thought oh when we're like a few customers sitting together and (inaudible)

\section{[}

let's not work about I'm sorry to keep pushing you back to this but let's not go into the detail of it but let's think about your overall ai:ms for the lesson cos I mean I know however people sort of hear the word aims and shudder but I mean that's<smiles>[TlH]</smiles>
mhm

starting point it's what I want my learners to achieve what I want them to get better at what I want them to take away from the lesson so what were you hoping that your learners would get better at at the end of your lesson by the end of your lesson? Just like I was hoping that they would sort of be able to get together and plan a role play together () and use (inaudible)<smiles>[3H][3H]</smiles>

is being able to $\mathrm{pl}$ sorry to interrupt is being able to plan a ((slowly)) ro:le play () an appropriate aim for a language lesson?

(..) $\mathrm{mmm}(. .$.$) no$

So think think think in language terms if you can what sort of language development were you hoping for? I was hoping they'd sort of like go away from the lesson with thinking oh there's polite ways to a:sk questions Okay so one one of the things you were hoping for was to raise awareness of the fact that erm I think you mention it here um intonation might affect () how polite or impolite someone is yeah okay () but I mean your mai:n ()overall aim for the lesson that wasn't it was it? ((falling tone $)$ )

((very quietly)) No

So what was what would you say was your main overall aim for the lesson?

Mmm (.) I don't know really ((laughs)) yeah I just really was like I was thinking oh I've got to try and get them to practise speaking in natural conversation rather than () setting them exact words to say () I was a bit worried I thought all that's ((inaudible)) 
The trainer begins the section by asking a question. She makes a number of false starts before settling on 'what did you hope the students would get better at at the end of your lesson?'. Trainee A begins to reply but is interrupted by the trainer (line 5) who wants the trainee to focus on the aims for the lesson. The trainer's turn can be seen as face threatening in a number of ways: first it is an interruption; second, it challenges the relevance of trainee A's answer ('let's not go into the detail of it'); and third, she repeats her question, prefacing it with 'so' demonstrating that she has an agenda (Heritage and Sorjonen, 1994) which she feels is more important than the trainee's. Nevertheless, within the norms of interaction for feedback, at this point in the talk, the threats could be deemed reasonable hostility as the trainer is focusing on an area she wishes the trainee to improve. The trainee again attempts to answer the trainer's question (line 14) this time giving a more concrete aim for the lesson (planning a role play). However, before she can elaborate, the trainer once again interrupts to ask if planning a role play is an appropriate aim for a language lesson.

The trainee needs to decide how to respond to the challenge. She can either make a case for what she did and argue her point, or acquiesce to the trainer's view of the lesson, demonstrating compliance. The long pause after a holding position ' $\mathrm{mmm}$ ' (Locher, 2004, drawing on Chafe 1985, suggests that a long pause after a holding position utterance indicates a consideration of response) is followed by an agreement, 'no'. The trainer then takes the floor again to ask another question (line 20), this time focusing on her view that lesson aims should have a language focus. Once again there is mitigation ('if you can', 'sort of') but the question is direct and unambiguous. The trainee's answer is to suggest that asking politely was the language aim (line 22). The trainer seems to accept this as legitimate, referring to the trainee's lesson plan and acknowledging that intonation affects the realisation of politeness. However, almost immediately, the trainer dismisses this aim as ineffective as a the main aim for the lesson, asking, 'your main overall aim for the lesson, that wasn't it, was it?'. The tag on the end of the question leaves the trainee once more with little choice but to agree with the trainer, which she does (line 29). The quiet tone suggests, however, that her affirmation is equivocal.

The trainer's final question in this sequence is 'what would you say was your main overall aim for the lesson?', a question she has asked five times in various ways. So far, Trainee A has not been able to answer the question to the trainer's satisfaction. At line 32, the trainee thinks, (Mmmm + pause), admits ignorance ('I don't know really'), laughs, perhaps to cover embarrassment, utters some 'vague' phrases (Channell, 1994) before, perhaps in despair, coming up with the same aim the trainer had already roundly criticised 'practise speaking in natural conversation'.

As previously described, questioning is a generic task of the feedback conference. In this extract, however, the questioning took a slightly different turn to other questioning phases, displaying a number of the features of what Roberts and Sarangi (2001:183) label 'hyperquestioning', that is, 'repeated questioning within a turn without turn-taking pauses.... and a high rate of questioning across turns.. in an increasingly less abstract form' (ibid). The trainee's responses to the questions suggest that she found them face threatening - she speaks quietly, is positioned into agreeing with the trainer and at times seems confused. Nevertheless, it could be that the trainer is doing 'reasonable hostility' (Tracey, 2008: 170 ) that is, providing an acceptable level of face threat within the context. The trainer, for example, explicitly states that she is 'sorry to keep pushing [the trainee] back to this' (lines 5-6) which could be taken as legitimising the 'pushing back' that follows (in the form of 'hyper-questioning') by implicitly marking it as professionally necessary. What is more, like the speakers in Tracey's study, the trainer 'adorns' her FTAs with 'positive jewelry' (Tracey, 2008: 187), apologising twice, using the inclusive 'let's' (that is, we are talking about this 'together'), three times and agreeing at one point with trainee A, which Tracey argues shows that the speaker is not intending to hurt the recipient of the face attack. 
Comparing this section to other questioning phases suggests that it is teasing the limits of questioning with the generic conventions (there is repeated questioning within and across turns). Ethnographic data suggest that it either goes beyond them or that conforming to generic conventions does not, in the end, set aside the responsibility to be sensitive to face (see too Culpeper 2005). My field notes say of this conference:

\section{Extract 14}

It was clear by the end that this hadn't gone well in the trainer's opinion. Again there was an issue of aims. The trainer clearly thought the trainee's session was a bit pointless, and by the end of this feedback, I think the trainee thought so too.

What is more, interviews with the trainer and trainee after the course both identified this particular feedback as 'horrible': indeed, the trainer stated:

\section{Extract 15}

I did sort of give her the opportunity to talk about it later [that day], which she didn't take cos I think she was quite kind of () upset rightly to some extent because it wasn't pleasant for anyone. ....She then rang me the following day... to apologise for not wanting to talk about it

The trainee's capacity to comply with what happened in feedback despite the discomfort it caused her might have contributed to the trainer's positive evaluation of her. Indeed, despite repeated negative evaluation of her classes, this trainee passed the course.

\section{Conclusion}

From the analyses presented above, it can be seen that feedback conferences conform to generic conventions, within which some face threatening acts, such as negative evaluation and intensive questioning, are acceptable. Other face threatening acts, as has been shown, seem either to overstep the boundaries of the norms of interaction or at least trouble the boundaries of these norms. When this happens, the participants in feedback negotiate face as the discourse unfolds, sometimes mitigating the face threats post-hoc, sometimes intensifying the face threats, sometimes contesting the face threats and sometimes accepting them. In extract 4 , for example, Trainee $\mathrm{C}$ contests the negative evaluation levelled at her, and then uses humour and metaphor to position herself as context-savvy at the same time as undercutting the authority of the trainer when she admits, 'It's a fair cop'. In extract 8, Trainee $\mathrm{S}$ begins by resisting the requirement to deliver feedback, then seems to rethink his position and provides detailed evaluation. In extract 13 , the Trainer $M$ delivers a series of face threatening attacks on Trainee A, who complies with the hyper-questioning discourse despite the anxiety it produces. In all cases, it is only possible to analyse face in terms of the on-going discourse and the context of the feedback conference. Indeed, the analyses presented here also suggest that some epistemic authority for understanding the level of face threat lies with the participants, as the analyst can only indicate how a face threat is constructed but not how it is perceived.

This paper has also sought to make the case for examining linguistic and ethnographic data together in order to produce detailed and nuanced analyses. Analysis of linguistic data alone, as many researchers have shown, can enhance our theoretical understandings of face and of politeness. However, bringing the ethnographic data to bear provides distinctive insights 
into 'the dynamics of social and cultural production' (Rampton et. al, 2004) in this case in the feedback conference which a linguistic analysis alone does not always deliver.

\section{References}

Arundale R. 2006. Face as relational and interactional: a communication framework for research on face, face work. and politeness. Journal of Politeness Research Vol.2, p. 193 - 216 Arundale, R.B., Constituting face in conversation: Face, facework, and interactional achievement, Journal of Pragmatics (2010). Doi: 10.1016/j.pragma.209.12.021

Author 2008

Author 2010

Bakhtin, M. 1981. The dialogic imagination: four essays. Austin: University of Texas Press Bakhtin, M. 1986. Speech genres and other late essays. Austin: University of Texas Press Bargiela-Chiappini F. 2003. Face and politeness: new (insights) for old (concepts). Journal of Pragmatics Vol. 35, p.1453 -1469.

Blum-Kulka S. 1992. The metapragmatics of politeness in Isreali society. In Watts R., Ide S., and Ehlich K., (eds) Politeness in Language: Studies in its History, Theory and Practice. Berlin: Mouton de Gruyter

Bousfield, D. 2008. Impoliteness in Interaction. Amsterdam: Benjamins

Bousfield, D. 2010. Researching impoliteness and rudeness: issues and definitions. In Locher, M.A. and Graham, S.L. (eds) Interpersonal Pragmatics. Berlin: De Gruyter Mouton

Bousfield, D. and Locher, M. (2008) Introduction: impoliteness and power in language. In Bousfield, D. and Locher, M (eds) Impoliteness in Language: studies on its interplay with power in theory and practice. Berlin: De Gruyter Mouton

Briggs, C.L. and Baumann, R. 1992. Genre, intertextuality, and social power. Journal of Linguistic Anthropology. Vol.2 (2), p. 131 - 172

Brown P. and Levinson S. 1987. Politeness: Some universals in language use. Cambridge:

Cambridge University Press

Chafe W. 1985. 'Some reasons for hesitating'. In Tannen D. and Saville-Troike M. (eds)

Perspectives on Silence. Norwood: Ablex Publishing Corporation

Channell J. 1994. Vague Language. Oxford: Oxford University Press

Cotterill, J. 2010. Interpersonal issues in court: Rebellion, resistance and other ways of behaving badly. In Locher, M.A. and Graham, S.L. (eds) Interpersonal Pragmatics. Berlin: De Gruyter Mouton

Creese A. 2007 Linguistic Ethnography. In Creese, A. Martin, P. and Hornberger N.H. (Eds) Encyclopedia of Language and Education. Volume 9. Springer Science and Business Media LLC

Creese A. 2008. 'Linguistic Ethnography'. In King K.A. and Hornberger N. H. (Eds)

Encyclopedia of Language and Education, $2^{\text {nd }}$ edition, Volume 10 Research Methods in

Language and Education Springer Science and Business Media LLC.

Culpeper J. 2005. Impoliteness and entertainment in the television quiz show The Weakest

Link. Journal of Politeness Research 1, p. $35-72$

Culpeper, J. 2008. Reflections on impoliteness, relational work and power. In Bousfield, D. and Locher, M (eds) Impoliteness in Language: studies on its interplay with power in theory and practice. Berlin: De Gruyter Mouton

Eelen G. 2001. A Critiques of Politeness Theories. Manchester: St. Jerome Publishing Emerson R.M., Fretz R.I., and Shaw L.L 1995. Writing Ethnographic Fieldnotes. Chicago: The University of Chicago Press. 
Garcia-Pastor, M.D., 2008. Political campaign debates as zero-sum games: Impoliteness and power in candidates' exchanges. In Bousfield, D. and Locher, M (eds) Impoliteness in Language: studies on its interplay with power in theory and practice. Berlin: De Gruyter Mouton

Geyer, N. 2010. 'Teasing and ambivalent face in Japanese multi-party discourse.' Journal of Pragmatics Vol 42, 2120 -2130

Goffman E. 1967. On Face Work. In Interactional Ritual. New York: Basic Books.

Goffman E. 1981. Forms of Talk. Philadelphia: University of Pennsylvania Press

Gu Y. 1990. Politeness Phemonena in Modern Chinese. Journal of Pragmatics Vol.14, p. 237257

Günthner S. and Knoblauch H. 1995. Culturally patterned speaking practices - the analysis of communicative genres. Pragmatics Vol 5 (1) p. 1 -32

Haugh M. 2007. The discursive challenge to politeness research: An interactional alternative. Journal of Politeness Research Vol. 3, p. 295 - 317

Haugh, M. and Bargiela-Chiappini F. 2010.Face in Interaction. Journal of Pragmatics Vol 42

(8) $2073-2077$

Hay J. 2000. Pragmatics of humour in in the conversations of men and women. Journal of Pragmatics 25 (2) p. 227- 255

Heritage J. and Sorjonen M. 1994. Constituting and maintaining activities across sequences: And-prefacing as a feature of question design. Language in Society Vol. 23, p $1-29$

Holmes, J. and M. Stubbe (2003). Power and Politeness in the Workplace: A

Sociolinguistic Analysis of Talk at Work. London: Pearson.

Holmes, J., and Marra, M. 2004. Relational practice in the workplace: Women's talk or gendered discourse? Language in Society 33, p. 377-398

Holmes, J., and Schnurr, S. 2005. Politeness, humour and gender in the workplace:

Negotiating norms and identifying contestation. Journal of Politeness Research Vol 1 (1), p.121 -149

Hyland F. and Lo M. 2006. Examining interaction in the teaching practicum: issues of language, power and control. Mentoring and Tutoring 14 (2) $163-186$

Ide S. 1993. Linguistic politeness, III: linguistic politeness and universality. Multilingua 12 (1) Limburg, H., 2008. Threats in conflict talk: Impoliteness and manipulation. In Bousfield, D. and Locher, M (eds) Impoliteness in Language: studies on its interplay with power in theory and practice. Berlin: De Gruyter Mouton

Locher M. 2004. Power and Politeness in Action: Disagreements in Oral Communication. New York: Mouton de Gruyter

Mullany, L. 2008. 'Stop hassling me!' Impoliteness, power and gender identity in the professional workplace. In Bousfield, D. and Locher, M (eds) Impoliteness in Language: studies on its interplay with power in theory and practice. Berlin: De Gruyter Mouton

Partington, A. (2006). The linguistics of laughter: A corpus-assisted study of laughter-talk.

London: Routledge

Pomerantz A. 1984. Agreeing and disagreeing with assessments: some features of preferred/dispreferred turn shapes. In Atkinson J.M. and Heritage J. (eds) Structures of Social Action. Cambridge: Cambridge University Press

Rampton B. 2006. Language in Later Modernity:interaction in an urban school. Cambridge:

Cambridge University Press

Rampton B. 2007. Neo-Hymesian Linguistic Ethnography in the UK. Journal of Sociolinguistics. Vol. 11 (5), 1 -19

Rampton, B., Tusting, K., Maybin, J., Barwell, R., Creese, A. and Lytra, V.2004. Linguistic Ethnography in the UK: A Discussion Paper. At http://www.ling-ethnog.org.uk 
Roberts C. and Sarangi S. 2001. "Like your're living two lives in one go": negotiating different social conditions for classroom learning in a further education context in Britain. In Heller M. and Martin-Jones M. (eds) Voices of Authority: Education and Linguistic Difference. Westport, CT: Ablex

Sacks, H. (1992). Lectures on conversation Oxford: Blackwell.

Soilevuo Grønnerød J. 2004. 'On the Meanings and Uses of Laughter in Research Interviews: Relationships between Interviewed Men and a Woman Interviewer', Young Vol.12, p. 31-49 Spencer-Oatey H. 2002. Managing rapport in talk: Using rapport sensitive incidents to explore the motivational concerns underlying the management of relations. Journal of Pragmatics Vol. 34 , p. $529-545$

Spencer-Oatey H. 2007. Theories of identity and the analysis of face. Journal of Pragmatics Vol. 39, p. $639-656$

Terkourafi, M. (2008) Toward a unified theory of politeness, impoliteness and rudeness. In Bousfield, D. and Locher, M (eds) Impoliteness in Language: studies on its interplay with power in theory and practice. Berlin: De Gruyter Mouton

Thompson J.B. 1991. Editor's Introduction. Language and Symbolic Power. Cambridge Mass.: Polity Press

Thonus, T. 2008. Acquaintanceship, familiarity, and coordinated laughter in writing tutorials. Linguistics and Education Vol. 19, 333 - 350

Tracy, K. 2008. "'Reasonable Hostility": Situation-appropriate face attack'. Journal of Politeness Research Vol 4, 169 - 191

Tusting K. and Maybin J. 2007. 'Linguistic ethnography and interdisciplinarity: Opening the discussion'. Journal of Sociolinguistics Vol 11 (5), 575 - 583

Waite D. 1995. Rethinking Instructional Supervision: Notes on its Language and Culture. London: The Falmer Press

Watts R. 2003. Politeness. Cambridge: Cambridge University Press

Wetherell M. 2007. A step too far: Discursive psychology, linguistic ethnography and questions of identity. Journal of Sociolinguistics. Vol. 11 (5), 662-681 